\title{
Treatment of bilateral popliteal artery aneurysms
}

\author{
Tratamento de aneurisma de artéria poplítea bilateral \\ José Aderval Aragão', (10, Fabio Guilherme Gonçalves de Miranda3a, lapunira Catarina Sant'Anna Aragão4, \\ Felipe Matheus Sant'Anna Aragão4, Francisco Prado Reis²
}

\begin{abstract}
Popliteal artery aneurysms are the most frequent type of peripheral aneurysm, accounting for $85 \%$ of the all of these aneurysms. Usually asymptomatic, they are generally diagnosed during clinical examination. Incidence is higher among males and seniors. They are bilateral in $50 \%$ of the cases and $60 \%$ are associated with abdominal aortic aneurysms. This paper describes a 72-year-old male patient who presented with two bilateral pulsatile masses, one in each popliteal region, was otherwise asymptomatic, and had a history of hypertension and dyslipidemia. Clinical examination and ultrasound imaging confirmed a diagnosis of bilateral aneurysms of the popliteal arteries. Popliteal artery aneurysms can be treated with open bypass surgery, with or without aneurysm resection, or with endovascular surgery. This Therapeutic Challenge discusses these possibilities.
\end{abstract}

Keywords: aneurysm, popliteal artery; peripheral arterial disease; peripheral vascular diseases; chronic disease; hypertension; vascular surgical procedures.

\section{Resumo}

O aneurisma de artéria poplítea (AAP) é o mais frequente dos aneurismas periféricos, correspondendo a $85 \%$ do total de aneurismas. Normalmente, são assintomáticos, e o diagnóstico, em geral, é feito por meio do exame físico, tendo uma maior incidência no sexo masculino e em idosos. São bilaterais em $50 \%$ dos casos e, em $60 \%$ das vezes, estão associados a aneurisma de aorta abdominal. Apresentamos um paciente do sexo masculino com 72 anos de idade, com duas massas pulsáteis em ambas as regiões poplíteas, assintomático, com história de hipertensão arterial e dislipidemia. Os exames clínico e de imagem ultrassonográfica confirmaram o diagnóstico de aneurisma bilateral de artéria poplítea. Os AAP podem ser operados por meio de derivações por cirurgia aberta, com ou sem resseção do aneurisma ou por meio de cirurgia endovascular. Esse desafio discute estas possibilidades.

Palavras-chave: aneurisma; artéria poplítea; doença arterial periférica; doenças vasculares periféricas; doença crônica; hipertensão arterial sistêmica; procedimentos cirúrgicos vasculares.

How to cite: Aragão JA, Miranda FGG, Sant'Anna Aragão IC, Sant'Anna Aragão FM, Reis FP. Treatment of bilateral popliteal artery aneurysms. J Vasc Bras. 2020;19:e20180142. https://doi.org/10.1590/1677-5449.180142 


\section{INTRODUCTION}

Popliteal artery aneurysms account for approximately $85 \%$ of all peripheral arterial aneurysms and are bilateral in $50 \%$ of patients. ${ }^{1,2}$ They are more common among males and the elderly. ${ }^{3}$ Among younger patients, a relationship has been observed with osteochondroma. ${ }^{4,5}$ In the majority of cases, these aneurysms are asymptomatic, although as volume increases they can cause pain and edema due to compression of nerves and veins. ${ }^{6}$

Popliteal artery aneurysms rarely rupture and their most significant complications are thrombosis and embolization. ${ }^{7}$ Treatment is surgical, which can be accomplished using endovascular procedures or open surgery (interposition or bypass with the great saphenous vein reversed or a prosthetic graft), with or without resection of the aneurysm. ${ }^{8-10}$ This Therapeutic Challenge will discuss these possibilities.

\section{Part I - Clinical situation}

The patient was a 72-year-old male who presented with bilateral popliteal artery aneurysms, was otherwise asymptomatic, and had a history of arterial hypertension and dyslipidemia. On physical examination there were palpable pulsatile masses suggestive of aneurysms in both popliteal regions, with no thrill or murmur in either limb. Dorsal pedal and posterior tibial pulses were palpable and the ankle-brachial index at rest was normal on both sides. No signs of ischemia were observed and no other vascular disorders were found in the lower limbs. Duplex scanning of the lower limbs revealed two popliteal artery aneurysms: one on the right measuring approximately $2.05 \mathrm{~cm}$ at its maximum diameter and $3.43 \mathrm{~cm}$ in length (Figure 1A), and the other on the left, with a maximum diameter of $1.72 \mathrm{~cm}$ and length of $3.26 \mathrm{~cm}$ (Figure 1B). There are a number of therapeutic possibilities in such a situation:

1- Endovascular procedure;

2- Open surgery via medial access with interposition or bypass using the great saphenous vein or prosthetic graft, with or without resection of the aneurysm sac;

3- Open surgery via posterior access with interposition of the great saphenous vein or prosthetic graft, with or without resection of the aneurysm sac.

\section{Part II - What was done}

Under epidural anesthesia, a surgical procedure to resect the aneurysm was performed in each lower limb, with a 90-day interval. The popliteal fossae were approached via a longitudinal, S-shaped incision through the skin and subcutaneous tissue. After dissection and

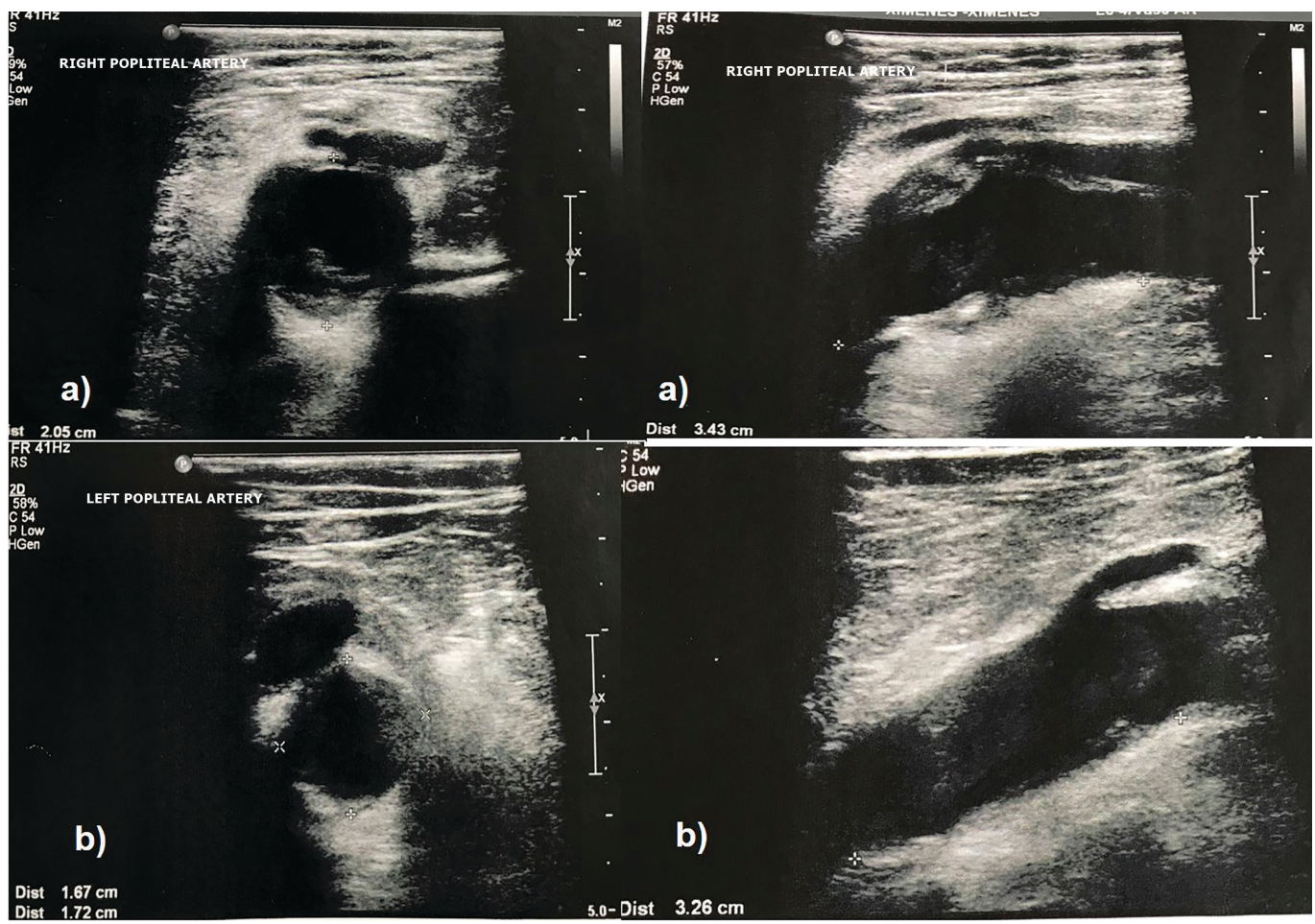

Figure 1. Aneurysmal dilatation of the right (a) and left (b) popliteal arteries, with mural thrombus visible on ultrasound. 
exposure of the popliteal artery aneurysms (Figure 2), the proximal and distal portions were repaired and clamped and the isolated stumps were sectioned, followed by resection of the PAAs (Figure 3) and interposition of the reversed great saphenous veins in the popliteal-popliteal segment (Figure 4).

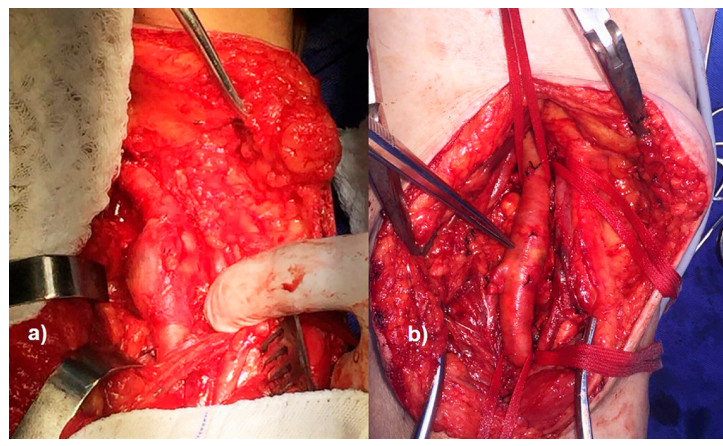

Figure 2. Surgical exposure of popliteal artery aneurysms, a saccular aneurysm on the right (a) and a fusiform aneurysm on the left (b).

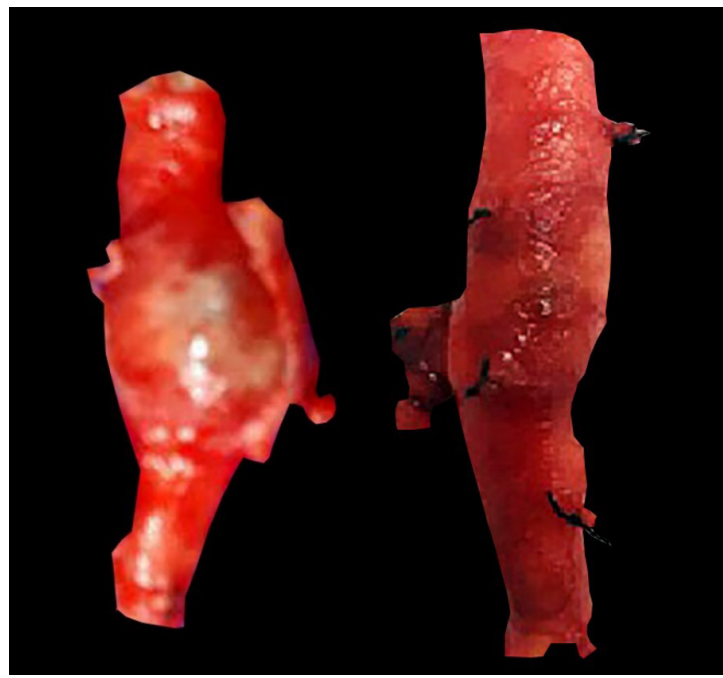

Figure 3. Surgical resection of a popliteal artery aneurysm.

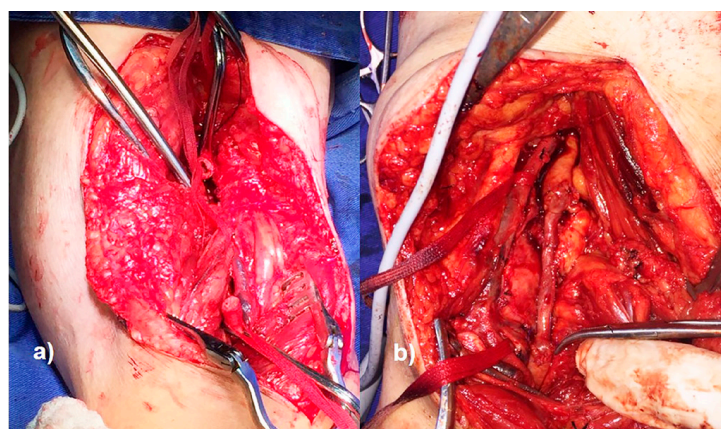

Figure 4. Exposure of the proximal and distal stumps (a) and popliteal-popliteal interposition of the reversed great saphenous vein (b).

\section{DISCUSSION}

Popliteal artery aneurysms are the most common type of peripheral aneurysm, in $50 \%$ of cases they present bilaterally, and they can be found coexisting with abdominal aortic aneurysms in $60 \%$ of cases. ${ }^{2}$ Although $80 \%$ of them are asymptomatic at the time of diagnosis, ${ }^{11}$ they tend to become symptomatic over time, at a rate of $14 \%$ per year. ${ }^{12}$ In contrast with aneurysms of the abdominal aorta, in which rupture is the major complication, popliteal artery aneurysms are prone to thrombosis with acute ischemia and risk of limb loss. ${ }^{13,14}$ Popliteal aneurysms are often asymptomatic and in general diagnosis is made by physical examination, by palpation of a wide arterial pulse in the popliteal fossa and, incidentally, by imaging exams (ultrasound, angiotomography, and magnetic resonance), which are also used to complement diagnosis and improve surgery planning, primarily when endovascular repair will be attempted. ${ }^{9}$ At our service, we normally use ultrasound as the method of choice for anatomic studies of the popliteal artery, because it is a cheaper method that is noninvasive and can be repeated easily, without harm to the patient. ${ }^{15,16}$ However, the reliability of ultrasound measurements is examiner dependent. ${ }^{17,18}$ The majority of vascular surgeons indicate surgery for PAAs with diameters greater than or equal to $2.0 \mathrm{~cm}$.

The classic treatment for a PAA consists of exclusion of the aneurysm with a bypass using an autologous or synthetic graft. ${ }^{19}$ The technique most often used is via a medial access with exclusion achieved by ligature of the popliteal artery upstream and downstream of the aneurysm, followed by popliteal -popliteal bypass with the great saphenous vein either reversed or devalved or with Dacron or PTFE grafts.

The advantages of this technique are its simplicity and reduced likelihood of trauma or iatrogenic injuries. Additionally, the saphenous vein can be accessed via the same incision. Disadvantages include maintenance of the thrombosed aneurysmal mass and patency of its localized branches, which may not entirely exclude the PAA. It is possible to entirely expose and open the PAA via this access, but in order to do so via this route of exposure it is necessary to section tendons and muscles at the level of the knee (semitendinosus, semimembranosus, gracilis, and gastrocnemius). The advantages of this larger exposure would be the possibility of removal of thrombi or of the aneurysm itself, of internal ligature of the branches, and of decompression of neighboring structures.

Another method (the one used in this case) is to use a posterior access with resection or opening of the aneurysm (similar to with an aortic aneurysm), ligature of the branches and interposition of a continues 
autologous or synthetic graft. The drawback of this access is the limited scope for access to the popliteal vessels and the possibility of injuring the fibular nerve. ${ }^{20}$ A saphenous vein with good caliber is the ideal graft material in these cases, since it is autologous, more malleable, more resistant to folding and to thrombosis, and less prone to infections. In the present case, surgical access to the aneurysms in both limbs was accomplished via a posterior route, which is usually considered preferable in cases with short aneurysms limited to the popliteal fossa. This procedure is as described by Pulli et al., ${ }^{21}$ who also employed this type of posterior approach to aneurysms limited to the popliteal fossa. According to Wagenhäuser et al., ${ }^{10}$ surgical access to a popliteal artery aneurysm can be achieved via medial or posterior routes and there is no significant difference in the long-term results.

Open surgical repair of aneurysms of the popliteal artery is a safe procedure with low rates of perioperative complications and excellent long term rates of both graft patency and limb salvage, particularly in asymptomatic cases. ${ }^{21}$ In the present case, there were no intercurrent conditions during the first 10 first months of follow-up.

Over recent years, endovascular exclusion of popliteal artery aneurysms has emerged as a new weapon in the arsenal of vascular surgery procedures available to vascular surgeons. ${ }^{22}$ This treatment option has grown in importance, especially for patients who have a high surgical risk or when no saphenous vein or prosthesis is available for grafting. ${ }^{9}$ Endovascular approaches are being used with increasing frequency as techniques and materials improve and because of their lower invasivity. This procedure is limited by the position of the stent, very often crossing the knee joint, which makes fatigue and fracture of the metallic material more likely. However, development of more flexible self-expanding stents has reaped more promising results. The results of the procedure are better in cases with good anatomy and at least two patent distal arteries. ${ }^{23}$

According to von Stumm et al. ${ }^{24}$ over the last two decades endovascular repair of popliteal artery aneurysms has proven comparable to open surgery over the medium term and it appears to be a safe alternative to conventional open surgical repair. However, Wagenhäuser et al. ${ }^{10}$ have concluded that open surgical repair remains the gold standard. Notwithstanding, endovascular repair has been performed with acceptable results in relation to open surgery. Comparative studies have shown primary patency rates in the range of 86.6 to $95.0 \%$ for endovascular techniques and 78.8 to $87.5 \%$ for open surgery using the saphenous vein as graft. ${ }^{25}$ However, the 30 and 90-day reintervention rates after the initial endovascular procedure are considerably higher than after open surgery. ${ }^{24}$

\section{CONCLUSIONS}

A review of the literature suggests that open surgical treatment of PAAs has similar patency rates to endovascular repair, with slightly higher surgical complication rates, although randomized comparative studies are limited. In the case described here, elective surgical intervention in a patient with low surgical risk and good life expectancy was a lasting therapeutic strategy that is appropriate and safe and achieves good initial and long-term results.

\section{REFERENCES}

1. Ferreira $M$, Medeiros A, Monteiro M, Lanziotti L. Alternativa técnica no tratamento endovascular dos aneurismas da artéria poplítea. J Vasc Bras. 2008;7(1):44-8. http://dx.doi.org/10.1590/ S1677-54492008000100008.

2. Domingues RB, Araújo ACO, van Bellen B. Tratamento endovascular de aneurisma de artéria poplítea: resultados em curto e médio prazo. Rev Col Bras Cir. 2015;42(1):37-42. http://dx.doi.org/10.1590/010069912015001008. PMid:25992699.

3. Galland RB. Popliteal aneurysms: from John Hunter to the 21st century. Ann R Coll Surg Engl. 2007;89(5):466-71. http://dx.doi. org/10.1308/003588407X183472. PMid:17688716.

4. Balachandran S, Murugesan R, Jayachander K, Muthukkaruppiah S. Popliteal artery aneurysms: Role of primary care physicians. J Family Med Prim Care. 2016;5(2):482-4. http://dx.doi.org/10.4103/22494863.192371. PMid:27843870.

5. Sethi S, Prakash M, Dhal A, Puri SK. Osteochondroma complicated by a popliteal vein aneurysm - a rare case report. J Clin Diagn Res. 2016;10(9):TD05-06. PMid:27790548.

6. Wissgott $\mathrm{C}$, Lüdtke $\mathrm{CW}$, Vieweg $\mathrm{H}$, et al. Endovascular treatment of aneurysms of the popliteal artery by a covered endoprosthesis. Clin Med Insights Cardiol. 2014;8(Suppl 2):15-21. http://dx.doi. org/10.4137/CMC.S15232. PMid:25574145.

7. Chen $\mathrm{CH}$, Wen JS, Wang CK. Huge pseudoaneurysm and cystic adventitial disease from popliteal artery entrapment. Circulation. 2015;132(13):1284-5. http://dx.doi.org/10.1161/ CIRCULATIONAHA.115.018399. PMid:26416631.

8. Serrano Hernando FJ, Martínez López I, Hernández Mateo MM, et al. Comparison of popliteal artery aneurysm therapies. J Vasc Surg. 2015;61(3):655-61. http://dx.doi.org/10.1016/j.jvs.2014.10.007. PMid:25499705.

9. Ronchey S, Pecoraro F, Alberti V, et al. Popliteal artery aneurysm repair in the endovascular era: fourteen-years single center experience. Medicine (Baltimore). 2015;94(30):e1130. http:// dx.doi.org/10.1097/MD.0000000000001130. PMid:26222843.

10. Wagenhäuser MU, Herma KB, Sagban TA, Dueppers P, Schelzig $\mathrm{H}$, Duran M. Long-term results of open repair of popliteal artery aneurysm. Ann Med Surg (Lond). 2015;4(1):58-63. http://dx.doi. org/10.1016/j.amsu.2015.01.005. PMid:25905015.

11. Galland RB. History of the management of popliteal artery aneurysms. Eur J Vasc Endovasc Surg. 2008;35(4):466-72. http:// dx.doi.org/10.1016/j.ejvs.2007.11.011. PMid:18180184. 
12. Cross JE, Galland RB. Part one: for the motion asymptomatic popliteal artery aneurysms (less than $3 \mathrm{~cm}$ ) should be treated conservatively. Eur J Vasc Endovasc Surg. 2011;41(4):445-8, discussion 449. http://dx.doi.org/10.1016/j.ejvs.2011.02.007. PMid:21453861.

13. Martelli E, Ippoliti A, Ventoruzzo G, De Vivo G, Ascoli Marchetti A, Pistolese GR. Popliteal artery aneurysms. Factors associated with thromboembolism and graft failure. Int Angiol. 2004;23(1):54-65. PMID: 15156131.

14. Thompson $M M$, Bell PR. $A B C$ of arterial and venous disease. Arterial aneurysms. BMJ. 2000;320(7243):1193-6. http://dx.doi. org/10.1136/bmj.320.7243.1193. PMid:10784548.

15. Wright LB, Matchett WJ, Cruz CP, et al. Popliteal artery disease: diagnosis and treatment. Radiographics. 2004;24(2):467-79. http:// dx.doi.org/10.1148/rg.242035117. PMid:15026594.

16. Wolf YG, Kobzantsev Z, Zelmanovich L. Size of normal and aneurysmal popliteal arteries: a duplex ultrasound study. J Vasc Surg. 2006;43(3):488-92. http://dx.doi.org/10.1016/j.jvs.2005.11.026. PMid: 16520160.

17. Beales L, Wolstenhulme S, Evans JA, West R, Scott DJ. Reproducibility of ultrasound measurement of the abdominal aorta. $\mathrm{Br} J$ Surg. 2011;98(11):1517-25. http://dx.doi.org/10.1002/bjs.7628. PMid:21861264.

18. Gürtelschmid M, Björck M, Wanhainen A. Comparison of three ultrasound methods of measuring the diameter of the abdominal aorta. Br J Surg. 2014;101(6):633-6. http://dx.doi.org/10.1002/ bjs.9463. PMid:24723017.

19. Kauffman P, Puech-Leão P. Tratamento cirúrgico do aneurisma da artéria poplítea: experiência de 32 anos. J Vasc Bras. 2002;1(1):5-14.

20. Yoshida RA, Yoshida WB, Sardenberg T, Sobreira ML, Rollo HA, Moura R. Fibular nerve injury after small saphenous vein surgery. Ann Vasc Surg. 2012;26(5):729.e11-5. http://dx.doi.org/10.1016/j. avsg.2011.11.042. PMid:22664286.

21. Pulli R, Dorigo W, Troisi N, et al. Surgical management of popliteal artery aneurysms: which factors affect outcomes? J Vasc Surg. 2006;43(3):481-7. http://dx.doi.org/10.1016/j.jvs.2005.11.048. PMid:16520159.

22. Pulli R, Dorigo W, Castelli P, et al. A multicentric experience with open surgical repair and endovascular exclusion of popliteal artery aneurysms. Eur J Vasc Endovasc Surg. 2013;45(4):357-63. http:// dx.doi.org/10.1016/j.ejvs.2013.01.012. PMid:23391602.
23. Antonello M, Frigatti P, Battocchio P, et al. Open repair versus endovascular treatment for asymptomatic popliteal artery aneurysm: results of a prospective randomized study. J Vasc Surg. 2005;42(2):185-93. http://dx.doi.org/10.1016/j.jvs.2005.04.049. PMid:16102611.

24. von Stumm M, Teufelsbauer H, Reichenspurner H, Debus ES. Two decades of endovascular repair of popliteal artery aneurysm--a meta-analysis. Eur J Vasc Endovasc Surg. 2015;50(3):351-9. http:// dx.doi.org/10.1016/j.ejvs.2015.04.036. PMid:26138062.

25. Braga AFF, Catto RC, Ribeiro MS, Piccinato CL, Joviliano EE. Cirurgia aberta e endovascular no tratamento de aneurisma de artéria poplítea: experiência de cinco anos do HCRP-FMRP-USP.J Vasc Bras. 2015;14(4):297-304. http://dx.doi.org/10.1590/1677-5449.02715.

Correspondence José Aderval Aragão Av. Marechal Rondon, s/n - Jd. Rosa Elze CEP 49100-000 - São Cristóvão (SE), Brasil Tel.: + 55 (79) 99191-6767 E-mail:adervalufs@gmail.com

Author information JAA - PhD in Sciences, Universidade Federal de São Paulo (UNIFESP). FGGM - Chief, Serviço de Residência Médica em Cirurgia Vascular, Fundação Beneficência Hospital Cirurgia (FBHC). ICSA and FMSA - Medical students, Centro Universitário de Volta Redonda (UNIFOA). FPR - PhD in Biological Sciences, Instituto de Ciências Biológicas, Universidade de São Paulo (USP).

Author contributions Conception and design: JAA, FGGM, FPR Analysis and interpretation: JAA, FGGM, FPR Data collection: ICSAA, FMSAA Writing the article: JAA, FGGM, FPR Critical revision of the article: JAA Final approval of the article*: JAA, FGGM, ICSAA, FMSAA, FPR Statistical analysis: N/A. Overall responsibility: JAA

*All authors have read and approved of the final version of the article submitted to J Vasc Bras. 